\title{
A ritualised rethinking of what it meant to be "European" post-heroic age for ancient Greeks of the post-heroic age
}

\section{Citation}

Nagy, Gregory. 2019. "A ritualised rethinking of what it meant to be "European" post-heroic age for ancient Greeks of the post-heroic age," in Thinking the Greeks : A Volume in Honour of James M. Redfield, edited by James M. Redfield, Bruce Michael King, and Lillian Eileen Doherty, 173-187. Routledge Monographs in Classical Studies. Abingdon, Oxon ; New York, NY: Routledge, 2019.

\section{Published Version}

https://chs.harvard.edu/CHS/article/display/6949

\section{Permanent link}

http://nrs.harvard.edu/urn-3:HUL.InstRepos:42181766

\section{Terms of Use}

This article was downloaded from Harvard University's DASH repository, and is made available under the terms and conditions applicable to Other Posted Material, as set forth at http:// nrs.harvard.edu/urn-3:HUL.InstRepos:dash.current.terms-of-use\#LAA

\section{Share Your Story}

The Harvard community has made this article openly available.

Please share how this access benefits you. Submit a story.

Accessibility 


\title{
A ritualized rethinking of what it meant to be 'European' for ancient Greeks of the post-heroic age: evidence from the Heroikos of Philostratus
}

\author{
Gregory Nagy
}

\section{Introduction}

In this essay, I will highlight a ritual as described in the Heroikos of Philostratus, 52.3-54.1. Dating from the early third century CE and composed in the context of an intellectual movement commonly known as the Second Sophistic, the Heroikos is an antiquarian compendium of rituals and myths originating from the region of ancient Troy. Viewing myth as a component of ritual, I will use the term ritual-myth complex in referring to examples of connectivity between myths and rituals, including the example that I will be highlighting.

To understand the ritual-myth complex that I have chosen, I find it most useful to start by applying the insights of James Redfield in his book The Locrian Maidens: Love and Death in Greek Italy (Princeton, 2003), hereafter abbreviated as LM. In this book, Redfield has not studied the ritual-myth complex that I will be studying here, but his methodology, as we will soon see, is nevertheless most relevant.

Redfield's book offers an incisive anthropological analysis of rituals and myths linked with the ancient Greek populations of diverse regions that identified themselves by way of a unified political name, Locris. I focus here on one particular Locrian ritual-myth complex as studied by Redfield, which centers on the idea that the sacrileges committed in the mythical past by the hero Ajax of Locris, the so-called Lesser Ajax of epic, must be expiated in the historical present by way of sending specially selected girls from their native Locris across the Aegean Sea to a city by the name of New Ilion. From here on, I will refer to this ritual-myth complex simply as the ritual of the Locrian Maidens.

As we will see, the setting for this ritual of the Locrian Maidens, the city of New Ilion, was an ideologically resurrected version of the old Troy of the Trojan War. And this same New Ilion, as we will also see, was the setting for the ritual-myth complex that we will see being described in the Heroikos of Philostratus, 52.3-54.1.

A primary source for the ritual of the Locrian Maidens comes from the notes or scholia that accompany an opaque poem dating from the third century BCE, the Alexandra of Lycophron. I will hereafter refer to these scholia as $\Sigma$, followed in each case by the numbering of the verses to which the given scholia refer. Particularly revealing are $\Sigma 365, \Sigma 1141, \Sigma 1152-1160, \Sigma 1167-$ $1168, \Sigma 1172-1173$.

The most relevant details to be learned from this primary source are summarized by Redfield at $L M$ 85-86. In the present paragraph I will now give a brief summary of Redfield's 
own summary. Basically, the Locrian Maidens are destined to expiate in New Ilion, year after year, the sacrilege committed by the Locrian hero Ajax when he violated the prophetess Cassandra inside the sacred space of the goddess Athena in old Troy. Accordingly, when the Locrian Maidens cross the Aegean Sea from their homeland in Europe and travel to the region controlled by the city of New Ilion in Asia Minor, which is figured as hostile territory, they have to undergo a ritualized ordeal of being treated as unwelcome intruders who deserve to be hunted down or even killed.

As Redfield shows at LM 86-150 in the analysis that follows his summary of the ancient reportage at LM 85-86, the hostile treatment of the Locrian Maidens when they reach New Ilion needs to be seen as a formalistic stylization in the world of ritual and myth. Such a world has its own rules, distinct from-though dependent on-the contingencies of the "real world" out there in the distant past. And, as Redfield also shows, historians need to analyze empirically not only the contingencies of such a "real world" but also the rules of the rituals and myths that existed inside that world-rules that had a world of their own. The rules of rituals and of the myths framed by the rituals need to be seen as a system, as a special language that operates within its own historical contexts. From a truly historical perspective, then, whatever happens to the Locrian Maidens in New Ilion is a seasonally recurrent staging, by way of ritual, that corresponds to what is narrated by way of myth. In other words, the historicity of the Locrian Maidens centers on their recurring participation in the world of ritual and myth.

Keeping in mind the insights of Redfield about the rituals and myths involving the Locrian Maidens, I am now ready to spotlight a comparable set of rituals and myths as described in the Heroikos of Philostratus, 52.3-54.1. This text of Philostratus, which I am about to quote, shows a ritual-myth complex involving Thessalians, figured as Aeolian Greeks inhabiting the European mainland, who must undertake a seasonally recurring west-to-east pilgrimage by crossing the Aegean Sea from their homeland in Europe and traveling to the region controlled by the city of New Ilion. As we will see, this city was at one time the cultural nerve center for Aeolian Greeks inhabiting the mainland of Asia Minor, and the territory of these Asiatic Aeolians was figured as notionally hostile to the European Aeolians from Thessaly.

An important point of comparison here is the fact that this same city of New Ilion was the ritual destination not only for the Thessalian pilgrims but also for Redfield's Locrian Maidens, for whom the region of Troy as controlled by New Ilion was likewise figured as notionally hostile territory.

So, the ritual-myth complex involving pilgrims from Thessaly is remarkably parallel to what we see in the ritual-myth complex involving the girls from Locris. And from here on, I will refer to this ritual-myth complex simply as the ritual of the Thessalians, corresponding to the term that I have already introduced, the ritual of the Locrian Maidens. 
In the ritual of the Thessalians, what they must accomplish is the notionally dangerous task of penetrating the hostile territory of New Ilion in order to perform a sacrifice to the hero Achilles, whose tomb was located within this territory and was claimed by the people of New Ilion as their own sacred possession. This ritual, as we will see, is an important piece of evidence for understanding in general the hero cults of Achilles and, in particular, some historical facts about the worship of Achilles as a cult hero. ${ }^{1}$

\section{The ritual of the Thessalians: text and translation}

I show here the text, with translation, of those parts of the Heroikos that highlight the ritualized surreptitiousness of a sacrifice to be performed by Thessalians worshipping Achilles as a cult hero in the region of Troy:

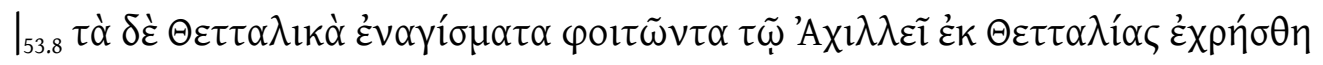

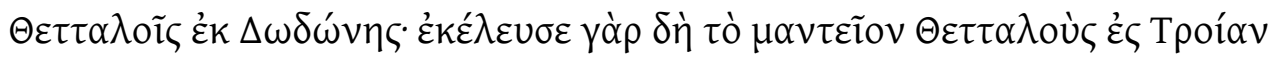

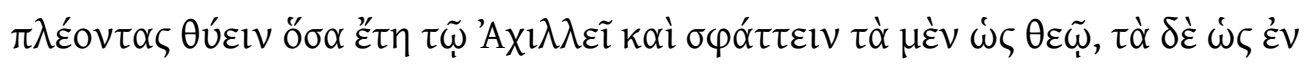

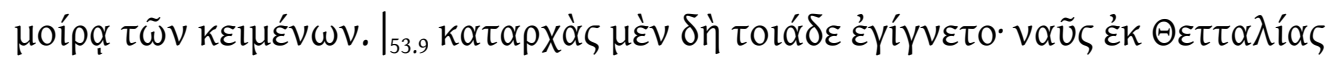

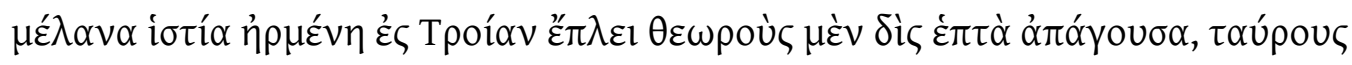

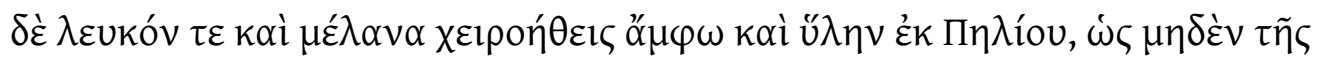

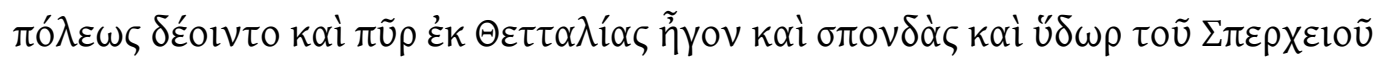

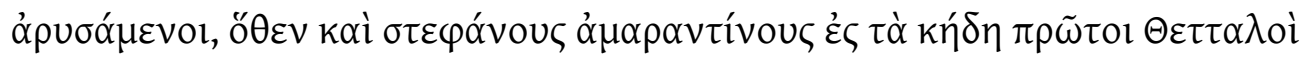

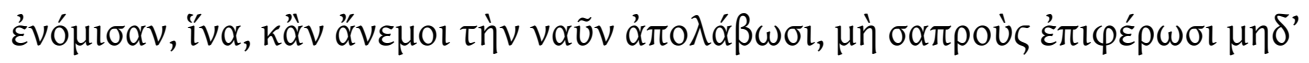

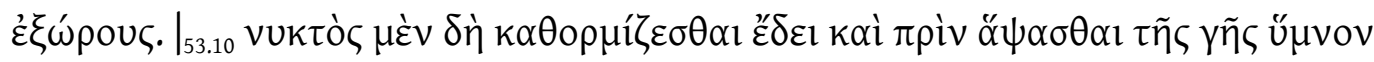

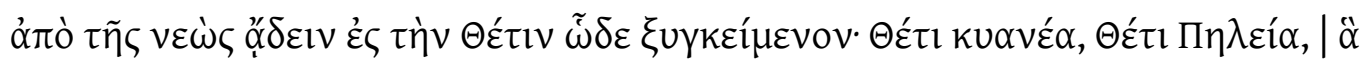

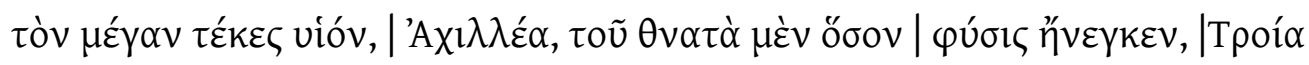

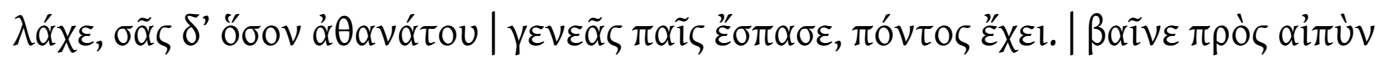

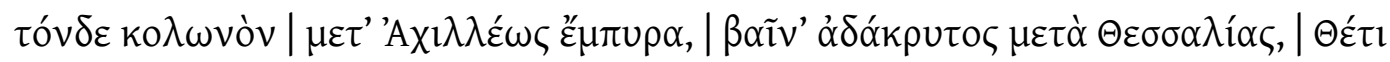

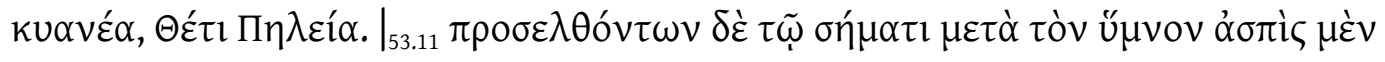

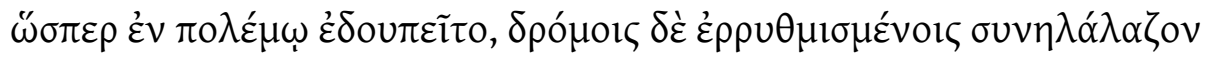

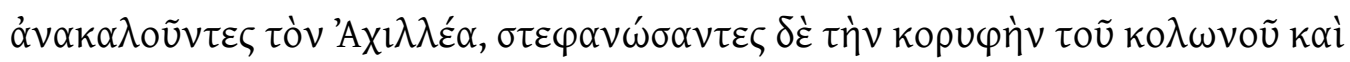

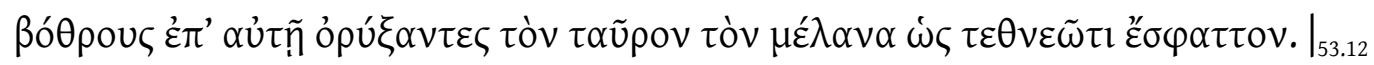

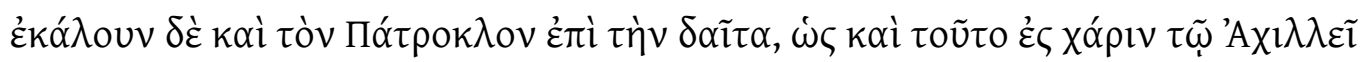

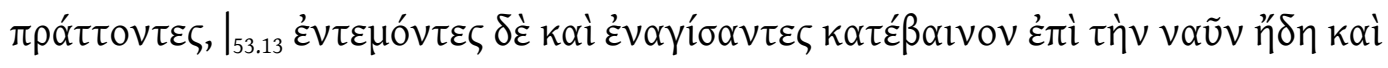

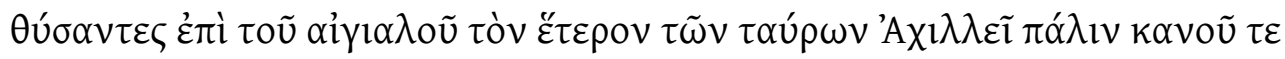

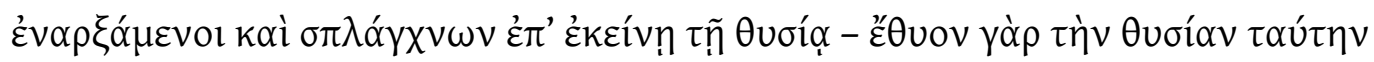

\footnotetext{
${ }^{1}$ For an introduction to the available evidence about Achilles as a cult hero, I cite my overview in Nagy 2012. On historical facts about hero cults in general, I recommend especially the work of Ekroth 2002 and 2009.
} 


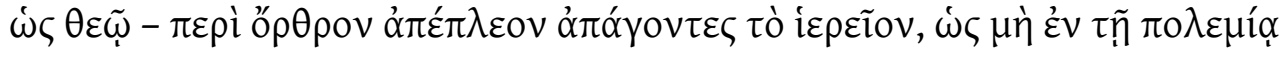

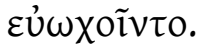

$\left.\right|_{53.8}$ The Thessalian sacrificial offerings [enagismata] that came regularly to Achilles from Thessaly were decreed for the Thessalians by the oracle at Dodona. You see, the oracle ordered the Thessalians to sail to Troy [= New Ilion] each year to sacrifice [thuein] to Achilles and to slaughter some sacrificial victims as for a god, while slaughtering other victims as for the dead. $\left.\right|_{53.9}$ From the very beginnings, the following was the procedure: a ship sailed from Thessaly to Troy with black sails raised, bringing twice seven sacred delegates [theōroi], one white bull and one black bull, both tame to the touch, and wood from Mount Pelion, so that they would need nothing from the city [= New Ilion]. They also brought fire from Thessaly as well as water drawn from the river Sperkheios for libations. As a consequence [of these practices], the Thessalians were the first to institute the custom of using unwilting garlands [stephanoi amarantinoi] for the funerary rituals [kédos plural] [in honor of Achilles], in order that, even if the wind delayed the ship, they would not wear garlands [stephanoi] that were wilted [saproi] or past their season [ex-hōroi]. $\left.\right|_{53.10}$ And evidently they found it necessary to put into the harbor at night and, before touching land, to sing from the ship a hymn [humnos] to Thetis.:

Thetis, sea-blue, Thetis consort of Peleus, | you who bore the great son | Achilles. The part of him that his mortal | nature brought him | was the share of Troy, but the part of him that from your immortal | lineage was drawn by the child, the sea [pontos] has that part. | Come, proceed to this steep tumulus [kolonos] | in the company of Achilles [to receive] the offerings placed over the fire. | Come, proceed without tears in the company of Thessaly, | you sea-blue Thetis, you consort of Peleus.

$\left.\right|_{53.11}$ When they approached the tomb [sèma] after the hymn [humnos], a shield was banged upon as in battle, and together with rhythmic coordination they cried alala while calling upon Achilles. When they had garlanded [stephanoûn] the summit of the tumulus [kolonos] and dug sacrificial pits on it, they slaughtered the black bull as to one who is dead. $\left.\right|_{53.12}$ They also called upon Patroklos to come to the feast, so as to gratify [= make kharis for] Achilles. $\left.\right|_{53.13}$ After they slit the victim's throat and made this sacrifice [enagizein], they evidently proceeded to go down to the ship, and, after sacrificing [thuein] the 
other bull on the beach again to Achilles and having begun the offering by taking from the basket and by partaking of the entrails for that sacrifice [thusiā] (for they sacrificed [thuein] that sacrifice [thusiā] as to a god), they sailed away as dawn approached, taking the sacrificed animal so as not to be feasting in the enemy's territory.

Philostratus Heroikos 53.8-13

\section{Preliminary answers to three pressing questions before proceeding}

One question... Can we rely on the information that we read here about the hero cult of Achilles? For me the long-range answer is yes. My cumulative experience in systematically comparing the lore transmitted by Philostratus with corresponding lore found elsewhere has convinced me that this author is meticulously accurate in his reportage of traditions. The reportage is quaint, yes, but this quaintness is I think merely a symptom of a most admirable antiquarian passion for uncovering precious details that remain hidden beneath the surface in earlier and more canonical forms of literature. ${ }^{3}$

A second question... Why is Achilles in his role as a cult hero so important to both European and Asiatic Aeolians? My long-range answer will be based on a variety of historical facts that we happen to know about rituals and myths centering on the hero cult of Achilles. These rituals and myths, as we will see, are shared by Aeolians on both sides of the Aegean Sea separating Europe and Asia Minor. And what they share, despite all the complexities we are about to encounter, is simple in its essence: from the standpoint of both sides, Achilles was born and raised in Aeolian Thessaly in Europe but died and was buried in the Aeolian territory of New Ilion in Asia Minor. As a cult hero, then, Achilles must be worshipped by Aeolians from both Europe and Asia. ${ }^{4}$

And a third question... What did it mean in the first place, for a Greek to be an Aeolian? From a purely linguistic point of view, a simple answer would be this: an Aeolian was whoever spoke a dialect known as Aeolic, which along with Doric and Ionic was a major dialectal grouping of the Greek language. From an anthropological point of view, however, there is more to it: as

\footnotetext{
${ }^{2}$ My translation here is based in part on an earlier rendition by Berenson and Aitken 2001:157, 159.

${ }^{3}$ See Nagy 2012:48-49, where I recommend the running commentary of Berenson and Aitken 2001:153-165. I also recommend there the eclectic comments of Grossardt 2006 II 719-722, though I have to express my friendly disagreement with his skeptical views concerning the historical value of the ritual details formulated by Philostratus. In Nagy 2013 (The Ancient Greek Hero in 24 Hours) "Hour" 14, I have much more to say about the testimony of Philostratus on hero cults, especially on the cult hero Protesilaos.

${ }^{4}$ For an introduction to the conflicting ideologies of European and Asiatic Greeks as analyzed by Herodotus and others, I offer an overview in Nagy 2014.
} 
we will see later when we consider the relevant remarks of Herodotus in the fifth century BCE, an Aioleus 'Aeolian' was whoever belonged to a social grouping of Greeks who distinguished themselves in their rituals and myths from other social groupings. Thus the Aioleîs 'Aeolians' were socially distinct from, say, Iōnes 'Ionians' and Dōriês 'Dorians'. And these differentiated social groupings of Aioleîs 'Aeolians' and Iōnes 'Ionians' and Dōrieîs 'Dorians' corresponded neatly with the linguistic groupings of the dialects spoken in Asia Minor and on its outlying islands:

1. The Aeolian speakers of Aeolic inhabited the northern part of coastal Asia Minor together with the outlying islands of Lesbos and Tenedos.

2. The Ionian speakers of Ionic inhabited the central part together with the outlying islands of Chios and Samos.

3. The Dorian speakers of Doric inhabited the southern part together with outlying islands like Rhodes.

By contrast with the dialects of these Asiatic Greeks, however, the corresponding dialects of the European Greeks inhabiting the mainland and islands on the other side of the Aegean Sea are in some cases more difficult to track linguistically. Such is the case with Aeolic dialects spoken on the European mainland, notably in Thessaly and in Boeotia. In the case of Thessaly in particular, the various dialects spoken in this overall region are difficult to correlate with the dialects spoken on the island of Lesbos and on the Asiatic mainland, but I argue that both these sets of European and Asiatic dialects are Aeolic; and I also argue for the relevance of the fact that the Thessalians figured themselves as true Aeolians in their rituals and myths. ${ }^{5}$

\section{Thirteen points about the historical background for the ritual of the Thessalians}

In a book entitled Homer the Preclassic (Berkeley, 2010), hereafter abbreviated as HPC, I analyzed in detail the historical background for what I have been calling the ritual of the Thessalians, and some aspects of that analysis are relevant to my present essay. Accordingly, I will now summarize those aspects in the form of thirteen points-while peeling away whatever details seem irrelevant for now.

Point 1. According to the Heroikos, the territory that figured as the ritual destination of the Thessalian sacrificers was controlled by the city of New Ilion, situated in the Troad, that is, in the region of old Troy. This city, New Ilion, was built on the ruins of the old Troy of the Trojan

\footnotetext{
${ }^{5}$ On Thessalians as Aeolians both linguistically and socially, see Nagy 2011. In that article I have much to say about Aeolian identity as defined by rituals and myths shared by Thessalians with their Aeolic-speaking counterparts on the other side of the Aegean. In that same article I engage in a friendly debate with Parker 2008 and Rose 2008 about the so-called Aeolian Migrataion. Some aspects of that debate will recur in what follows here.
} 
War as narrated in the epic that we know as the Homeric Iliad. Archaeologists have verified that Hisarlik, which is the Turkish name for the site of New Ilion, was in fact the same place as the site of old Troy, which was also known in the ancient world as Ilion. [HPC 131]

Point 2. After a major destruction of the citadel at old Troy sometime around the beginning of the 12th century BCE, which marks the end of a phase that archaeologists recognize as Troy VIIa, the importance of the site was radically diminished, and things stayed that way through the phase known as Troy VIIb, lasting into the 10th century BCE. After Troy VIIb comes Troy VIII, which marks a "Greek era" extending all the way to the so-called "Roman era" that is Troy IX. In the earliest phase of Troy VIII, from the 10th to the mid-7th century BCE, a small population was occupying the area of the citadel, and, on the western side of the citadel wall, they left behind some archaeological remains of a "place of memory" that must have commemorated in some way the epic traditions of the Trojan War. ${ }^{6}$ At a later phase of Troy VIII, in the mid-7th century BCE, there was a destruction, to be followed in the late 7th century by a reoccupation. From this time onward, in the latest phase of Troy VIII, we see the beginnings of the historical period. Now the old Troy is on its way to becoming the new Troy, that is, New Ilion.? [HPC 131.]

Point 3. As in modern times, the old Troy of New Ilion was sought out in antiquity, most prominently by rulers striving to link themselves with the heroes who fought in the Trojan War of the epic past. In 480 BCE, as we read in Herodotus 7.43.2, Xerxes the king of the Persian Empire traveled to New Ilion and made sacrifice there to the goddess Athena, and his magi made libations to the hêrōes 'heroes' who were buried in the environs. ${ }^{8}$ Over a century later, Alexander the Great likewise sacrificed to Athena in New Ilion (Strabo 13.1.26 C593; Arrian Anabasis 1.11.7). [HPC 131-132.]

Point 4. I highlight the term used by Herodotus here at 7.43.2 in referring to the goddess Athena as worshipped in her sacred space at New Ilion: she is he Ilias, meaning something like 'she who is in Ilion'. But the name can also be interpreted to mean 'she who is in the Iliad', in the sense that Ilias as an 'Iliad' means simply 'the song about Ilion'. [HPC 126.]

Point 5. Elsewhere, at 5.122.2, Herodotus uses the same expression he Ilias in referring to the territory of Ilion as inhabited by Aeolians. The context is this: a Persian general was redeploying his forces at the time of the Ionian Revolt, ongoing in the first decade of the 5th century BCE,

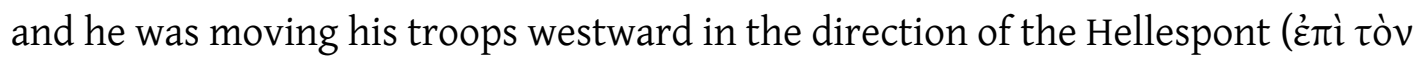

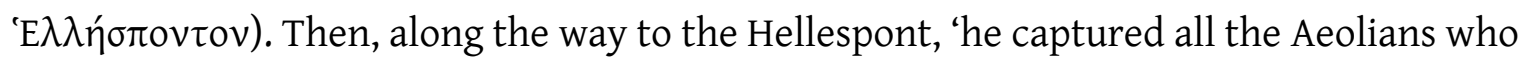

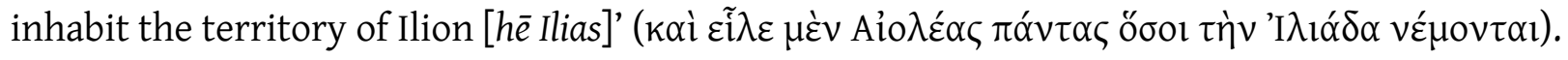

\footnotetext{
${ }^{6}$ Aslan and Rose 2013:11.

${ }^{7}$ On the historical and archaeological reality of the New Ilion, see the overview of Rose 2006.

${ }^{8}$ On the political motives of Xerxes, see Haubold 2004.
} 
This detail from Herodotus concerning hē Ilias as 'the territory of Ilion' is a most valuable piece of evidence showing that New Ilion was at this time inhabited by Aioleîs 'Aeolians'. I should add that there is a plethora of further evidence showing the Aeolian identity of New Ilion in the era of Troy VIII. [HPC 142-146.]

Point 6 . But now we must confront a big complication. This New Ilion was not the only 'new Ilion'. As early as the late seventh century BCE, a rival 'new Ilion' emerged, and its occupants claimed that their site was the real Troy of olden days. This alternative New Ilion was located not far from the old Troy, but it was a different site. The inherited name of the site was Sigeion, and it was situated on a promontory at Kum Kale, overlooking the entrance to the narrows of the Hellespont. ${ }^{9}$ [HPC 143; see the map at HPC 158.]

Point 7. Like the New Ilion that was built over the old Troy, the site of Sigeion used to be occupied by Aeolians. Also, for some time in the seventh century BCE, Sigeion had been dominated by Mytilene, which was then the most powerful city in Lesbos, an Aeolian island situated due west across the sea from the Aeolian mainland of Asia Minor. As we read in Strabo 13.1.38 C599, the Mytilenaeans under the leadership of one Arkheanax built the walls of the citadel of Sigeion from the stones of the ruined walls of the ancient citadel of Troy. Strabo thinks that this important piece of information validates arguments made in the second century BCE by the antiquarian Demetrius of Scepsis, who denied any continuity between the old Ilion and the city of New Ilion as it existed in his own day, claiming that there was no trace left of the old Ilion. Supposedly, all the stones of the old Ilion had been used up in the process of building the walls of other cities like Sigeion. But we have already seen at Point 2 that the stones of the old Ilion were in fact still very much in evidence throughout the phase known as Troy VIII, and so the arguments of Demetrius are invalidated. Still, the information reported by Demetrius and transmitted by Strabo about the re-using of stones from old Troy for the building of new Troys retains its full value. A shining example of another such new Troy was the Aeolian city of Neon Teikhos 'New Wall', which belonged to a confederation of twelve Aeolian cities situated on the mainland of Asia Minor and commonly known as the Aeolian Dodecapolis (Herodotus 1.149.1 lists them all). [HPC 145-146. About Neon Teikhos, see also HPC 180.]

Point 8. Unlike New Ilion, which remained an Aeolian site, the city of Sigeion underwent a drastic change in identity, and this happened already in the seventh century BCE. Somewhere around that time, control of Sigeion was seized by the Ionian city of Athens and taken away from the Aeolian city of Mytilene-in-Lesbos. I cannot go into details here about this drastic change, but I will at least highlight the fact that Sigeion is pictured as already belonging to

\footnotetext{
${ }^{9}$ Archaeologists have securely identified the site at Cape Yenişehir as Sigeion: see Burgess 2006; 2009:118-121. Also Cook 1973:178-186 and Aloni 1986:65n8.
} 
Athens in the poetry of Alcaeus, who can be dated to the late seventh century BCE. Herodotus notes that Alcaeus himself says in his own poetry that his armor was captured from him by the Athenians in a battle against the Mytilenaeans, and that it was displayed by the enemy at the Athênaion 'sacred space of Athena' in Sigeion. Here is the way Herodotus says it at 5.95.1: 'the Athenians have his [= Alcaeus'] armor and they have hung it up for display at the space of

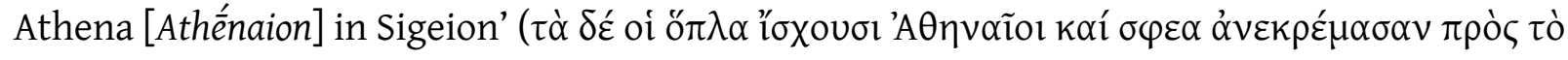

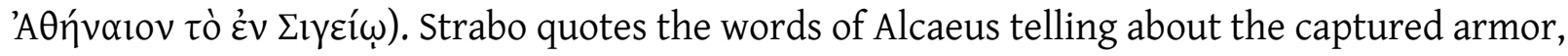
and these words actually give the name of Athena's sacred space as Glaukốpion (Alcaeus F 401B via Strabo 13.1.37 (600). This same name Glaukôpion, derived from the sacred epithet of Athena glaukôpis 'having the looks of the owl', is attested in Athens as well. There it applies to the sacred space of Athena Nike at the southwest corner of the acropolis (Callimachus F 238.11), and this space, like the Glaukốpion in Sigeion, can be dated at around 600 BCE..$^{10}$ [HPC 142-146. I include in those pages many further details about the protracted war between the Athenians and the Mytilenaeans over the possession of Sigeion.]

Point 9. Just as Athena had a sacred space in the new Ilion of Sigeion, so also she had her own sacred space in the New Ilion built on top of the old Troy, where as we have already read in Herodotus 7.43.2 the goddess was worshipped as he Ilias, meaning not only 'she who is in Ilion' but also 'she who is in the Iliad'. As I noted at Point 4, such an 'Iliad' was not the Homeric Iliad that we have but instead 'the song about Ilion' as it was known then-and as it was known even earlier when the occupants of Troy VIII were already venerating a "place of memory" commemorating the epic traditions of the Trojan War, as we saw at Point 2. [HPC 131.]

Point 10. There may be some uncertainties about positively identifying an earlier version of 'Iliadic' Athena-he Ilias-as the goddess who presided over the "place of memory" in the early phases of Troy VIII, but we can be quite certain about the actual linking of the old Troy with epic traditions about an old Troy. And here again the same expression he Ilias applies: at Point 5, we already saw that Herodotus 5.122.2 says he Ilias in referring to the territory of Ilion as inhabited by Aioleîs 'Aeolians'. But now we will see that Herodotus also uses the same expression hē Ilias in a context where he refers to a territory belonging not only to Ilion but also to the Iliadic tradition of poetry. The context is this: Herodotus is describing a scene where representatives of the cities of Mytilene and Athens, which have evidently already fought in many wars over the possession of Sigeion, are submitting their dispute to inter-state arbitration, and now the Aeolians of Mytilene are demanding that the Athenians give back to them the territory of Sigeion and its environs:

\footnotetext{
${ }^{10}$ Robertson 1996:70n55. Also Frame 2009 \$3.74. See also Rose 2006:142-143 on the temple of Athena at Assos, which was similar in its Doric architecture to the temple of Athena at Sigeion.
} 


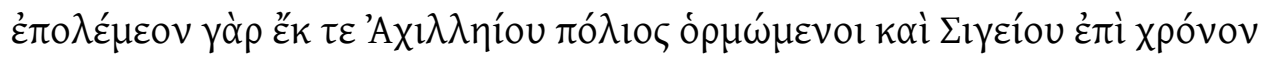

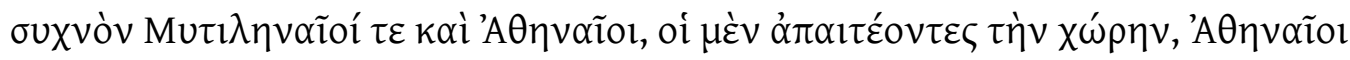

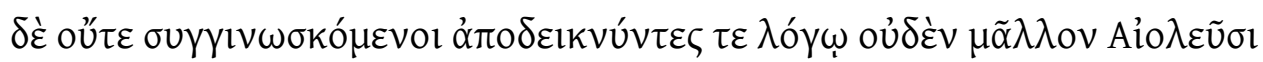

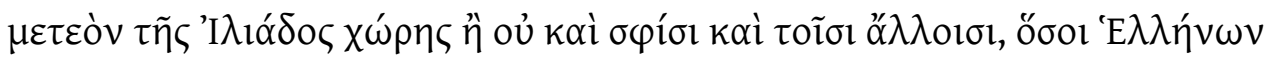

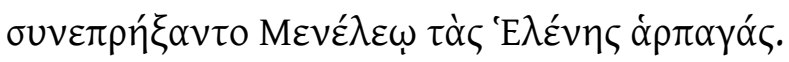

You see, the Mytilenaeans and the Athenians had been waging war with each other for the longest time. One side [= the Mytilenaeans] operated out of the city [polis] of Akhílleion and the other side [= the Athenians], out of Sigeion. They [= the Mytilenaeans] were demanding the return of the territory [khōrā], but the Athenians rejected the demand, trying to demonstrate by way of what they said that the Aeolians were no more entitled to the Iliadic territory [he Ilias khōrā] than were they [= the Athenians] and all the other Hellenes who had joined forces in avenging Menelaos for the abduction of Helen.

Herodotus 5.94.2

As the wording of Herodotus indicates, the city of Mytilene in Lesbos claimed to be representing all Aeolic-speaking Hellenes in claiming possession of the Iliadic territory of Sigeion in the Troad. By contrast, the city of Athens claimed to be representing all Hellenes who took part in the Trojan War. From the standpoint of both sides, then, the disputed territory is poetic as well as political. [HPC 145.]

Point 11. The poetic prestige of Sigeion depended not only on the walls of this Aeolian city, built from the stones of old Troy. It depended also on something else that once had an inestimable poetic value, and that something was the tomb of the hero Achilles. I have studied in some detail the references to this tomb in the Homeric Iliad and Odyssey, but my goal in the present essay is not to review what the poetry says about the tomb. ${ }^{11}$ Rather, my goal here is to study the ancient reception of what the poetry says, and this reception turns out to be a most complicated matter. Before I get into the complications, however, I should start by noting the simple fact that there exists a tumulus situated on the slopes stretching from the heights of the promontory of Sigeion-a tumulus that was once believed to be the tomb of Achilles. That said, however, I should also note that there exist other tumuli as well in the region of old Troy,

\footnotetext{
${ }^{11}$ For a brief review of what Homeric poetry does say about the tomb of Achilles, see Nagy 2012:48-51.
} 
and that the identification of the tumulus at Sigeion as the tomb of Achilles is conditioned, as we will now see, by the vicissitudes of history. ${ }^{12}$ [HPC 147-170.]

Point 12. When it comes to the reception of lore about the tomb of Achilles, one piece of evidence stands out. There is in fact an indirect reference to such a tomb in the passage I quoted at Point 10 from Herodotus 5.94.2, where the Mytilenaeans as they are fighting their wars with the Athenians are said to be operating out of a polis 'city' by the name of Akhílleion, while the Athenians on the other side are operating out of the city of Sigeion. The city of Akhílleion was built on the heights of a promontory at the Bay of Beşike, at the southern end of the Sigeion Ridge. ${ }^{13}$ This lofty ridge, some ten kilometers in length, extends along the Aegean coastline of Asia Minor from the promontory at the Bay of Beşike in the south all the way to the promontory at Kum Kale in the north, which as we have already seen is the location of Sigeion, a city looming over the point of entry from the Aegean Sea into the Hellespont. ${ }^{14}$ As we now contemplate the overall geography of the Sigeion Ridge and concentrate on the city of Akhílleion at the southern end of the heights, even the name of the city itself, 'the place of Achilles', indicates that its occupants considered it to be the site of the tomb of Achilles. And, as at Sigeion, so also at Akhíleion there is supporting archaeological evidence: in the vicinity of this city is a tumulus looking out over the Aegean sea, and this tumulus at Akhílleion, like the tumulus at Sigeion, was believed to be the tomb of Achilles. [HPC 148; see the map at HPC 158 for the positioning of both Sigeion and Akhíleion.]

Point 13. We need to account for the mutually contradictory existence of two tumuli, one at Sigeion and one at Akhílleion, as alternative tombs of Achilles. I propose that an explanation can be found in the historical context of the original dispute between the Athenians and the Mytilenaeans over the poetic real estate of old Troy. Here I return to the situation as described by Herodotus 5.94.2 at Point 10. Back in the late seventh century BCE, the Athenians could claim that the city of Sigeion, as their possession, was the new Troy, and they could base their claim on the premise that the walls of this city were built-or supposedly rebuilt-from the same stones that had been used for the building of the old Troy. At the same time, the Mytilenaeans could at least claim that the city of Akhíleion, which they retained while losing possession of Sigeion, was the site of the tumulus that contained the body of Achilles. From the standpoint of the Mytilenaeans, only the tumulus at Akhílleion would have been the true tomb of Achilles, while the tumulus at Sigeion was supposedly a false tomb. And of course the

\footnotetext{
${ }^{12}$ For a summary of archaeological evidence about the tumuli in the Troad, see especially Burgess 2006 . See also Cook 1973:185-186 and 1984:167-168; Aloni 1986:65n8; West 2002:208n8; Rose 1999:61-63, 2000:65-66, and 2006:140-141, 149.

${ }^{13}$ Archaeologists have securely identified the site at Cape Burun as Akhílleion: see Burgess 2006n56 and n58; 2009:122-123. Also Cook 1984:168.

${ }^{14}$ Cook 1984:167.
} 
Athenians could make a contradictory claim: from their standpoint, the tumulus at Sigeion was the real tomb. But such Athenian claims were not to last. Even the claim that Sigeion was the new Troy was doomed. And here is why. We now come to a most startling historical fact, recorded by Strabo 13.1.39 C600: in the end, the city of Sigeion was destroyed by the city of New Ilion. The geographer adds that Sigeion in his time was completely demolished (13.1.39 C600

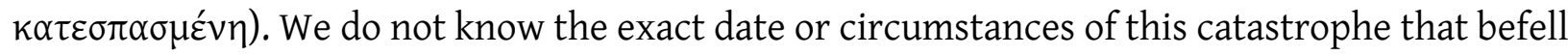
Sigeion in particular and Athenian prestige in general, but I estimate that it happened sometime in the second half of the fourth century BCE. By that time, the site of New Ilion was transformed into a spectacular city. Strabo 13.1.26 C593 reports that Alexander the Great transformed New Ilion from a kōme 'village' into a major polis 'city', and that the transformation was continued by Alexander's would-be successor Lysimachus. So, after the destruction of Sigeion, New Ilion could become what the old Ilion had once been, that is, the most dominant site of the Troad. Strabo goes out of his way to note the dominance of New Ilion in his own time (13.1.25 C593), when this Aeolian city controlled the Asiatic coastline of the Hellespont as far north as Dardanos (13.1.39 C600). So, despite all the setbacks that the Aeolians of the region of Troy had suffered at the hands of the Athenians ever since the late seventh century BCE-and the setbacks continued well into the late fifth century BCE-the Aeolians eventually recovered most of their cultural identity in the course of the fourth century BCE. That is why the entire paraliā 'coastline' of Asia Minor from Abydos in the far north all the way to Cyme in the far south could proudly be described as Aiolis 'Aeolian territory' by an Aeolian source dating to the second half of the fourth century BCE. The source here was a native of the Aeolian city of Cyme: he was a historian named Ephorus, FGH 70 F 163, and his testimony was transmitted by way of Strabo 13.1.39 C600. Strabo cites this testimony of Ephorus as an indication of the enduring power of Aeolian cultural identity-and, indirectly, of an ongoing Aeolian cultural resistance to Athenian political domination. [HPC 193; on the domination of the Aeolian territory of Troy by the Athenians in the fifth century BCE, see the details in HPC 192-193.]

\section{A reconstruction of the historical foreground for the ritual of the Thessalians}

Now that I have outlined, by way of the preceding thirteen points, the historical background for the ritual of the Thessalians, I am ready to attempt a reconstruction of the foreground, by which I mean the historical era and location of the ritual as pictured in the text of Philostratus, Heroikos 52.3-54.1. According to that text, as noted already at Point 1, the ritual destination of the Thessalian sacrificers was a tumulus that was understood to be the tomb of Achilles, and this tumulus was located in a territory that was controlled by the city of New 
Ilion. The detail about control of territory is decisive for determining both the era when this ritual was ongoing and its location. If New Ilion was in control, the era needs to be dated to a time when this city had the power to regulate any visits to any tumulus in the region of the Troad. And, if I am right in estimating how long the dominant power of Sigeion lasted in this region, from the late seventh all the way to the late fourth century $B C E$, then the terminus post quem for locating the Thessalian ritual at any tumulus in the Troad would be the late fourth century, by which time Sigeion would be finally out of the picture while New Ilion would now have its own power and authority to regulate visits to the tomb of Achilles. But which tumulus would be sanctioned as the tomb of Achilles from the standpoint of New Ilion as the new capital city of Aeolian Greeks in the Troad? I think that the tumulus at Akhilleion, which was all along an Aeolian city, would have now become the officially designated location for seasonal visits by theöroi or 'sacred delegates' whose mission was to worship Achilles as their cult hero. It is therefore no coincidence, I also think, that the tumulus at Akhílleion was considerably enlarged at about the same time, in the third century BCE. ${ }^{15}$

But why would the visits by the sacred delegates from Thessaly have to be surreptitious, as if the territory where the tomb of Achilles is located were controlled by a city that is hostile to them? I propose that the stylized surreptitiousness and hostility can be viewed as a ritualized dramatization of a historical fact: once upon a time, in the past, the Thessalians used to sacrifice at the tumulus at Sigeion, not at the tumulus at Akhilleion. Such a practice can be dated to the era when the Athenian possession of Sigeion was managed by a dynasty known as the Peisistratidai who ruled Athens in the sixth century BCE.

Before continuing, I need first to emphasize that the Thessalians, in sacrificing to Achilles in the Troad, would be performing that ritual as Aeolians. From the standpoint of their own ideology, Thessalians were Aeolians originating from-and still living in-the territory on the Helladic mainland where the Iliadic hero Achilles himself was reputedly born and raised. So these Aeolians could claim a special connection to the territory on the Asiatic mainland where Achilles died and was buried.

Such a claim, then, on the part of the Thessalians would have been most compatible with the agenda of Athens in the era of the Peisistratidai. Since the Athenians were dominating the territory of Troy by way of their outpost at the city of Sigeion, they could express their domination culturally by way of allying themselves with the Thessalians as notionally prototypical Aeolians. And it is relevant to note here that one of the sons of Peisistratos, Hegesistratos, was renamed Thessalos (in the Attic dialect, Thettalos) the 'Thessalian' (Aristotle Constitution of the Athenians 17.3-4), and we also know that this son was directly associated with Sigeion: during one phase of the period when Sigeion belonged to the Athenians, this man was

\footnotetext{
${ }^{15}$ For more on the enlargement of the tumulus at Akhílleion the third century BCE, see Rose 2006:149.
} 
put in charge as tyrant of the city (Herodotus 5.94.1). The Athenian tyrant's ad hoc name Thessalos evokes a special Athenian connection with the Aeolians who inhabited Thessaly. ${ }^{16}$ And Herodotus 5.63.3 actually highlights the ongoing alliance between the dynasts of Thessaly and the Peisistratidai of Athens. ${ }^{17}$

As I come to the end of my argumentation, I offer this formula for summarizing how the Thessalians had once been relevant to the political agenda of the Athenians:

These Aeolians on the Helladic mainland were the notional prototypes of the Aeolians on the island of Lesbos and, by extension, of the Aeolians on the Asiatic mainland. Thessaly was understood to be the point of origin for the Aeolian Migration, that is, for the colonization of the Aeolian cities on the island of Lesbos and, by extension, of the Aeolian cities on the Asiatic mainland. While the Athenians on the Helladic mainland figured themselves as the prototypes of the Ionians of Asia Minor and of its outlying islands, they figured the Thessalians as the prototypes of the Aeolians of Asia Minor and of its outlying islands, especially of Lesbos. ${ }^{18}$

What I have just formulated can be reconciled with two references in the Iliad to a most singular event: the capture of all Lesbos by a single hero, Achilles of Thessaly, 9.128-131, 270273. I argue that the story of this capture was originally a Thessalian charter myth that accounted for a prehistoric appropriation of Lesbos by the Thessalians. And this myth could also account for the later attempts of the Thessalians to assert themselves against Lesbos in the specific context of their alliance with the Athenians. So, in terms of such an alliance, the tomb of Achilles would be located not at the site of Akhilleion, as owned and operated by the Mytilenaeans of Lesbos, but at the site of Sigeion, as owned and operated by the Athenians. ${ }^{19}$

\section{Epilogue}

It is easy for us to forget the significance of Sigeion during the period extending from the late seventh to the mid-fourth century BCE, since it disappeared thereafter. In its glory days, however, this city could get away with being venerated as the real new Ilion, at the expense of the Aeolic New Ilion. And, even though the city of Sigeion was no longer Aeolic during this

\footnotetext{
${ }^{16}$ I have much more to say about this man's name Thessalos in HPC 148n6.

${ }^{17}$ HPC 148-149, following Shaw 2001:167n7.

${ }^{18}$ HPC 149. At HPC 142-143, I have much more to say about the so-called Aeolian Migration and on its correlation with the so-called Ionian Migration.

${ }^{19}$ This argument differs from what I argued in HPC 149,
} 
period, its Aeolic heritage could be legitimated by the Thessalians, who figured as the protoAeolians in the myths and rituals of all Aeolians.

So, the ritual of the Thessalians, as I have been calling it, can be seen as a seasonally recurrent act of ritual compensation for their having worshipped, once upon a time, a notionally false Achilles at a false tomb, at Sigeion. To do it right at the notionally real tomb of Achilles at Akhílleion, now controlled by the real Troy that was New Ilion, they would have to feel forever unwelcome, since they had failed in the past to recognize the real old Troy.

I see a comparable mentality at work in the ritual of the Locrian Maidens. They too, once upon a time, would have been sent to the false new Ilion at Sigeion, not to the New Ilion of the real old Troy. So, when New Ilion finally took control, the Locrian Maidens too would have had to feel unwelcome when they started coming to New Ilion on their pilgrimage. But at least they were allowed, if everything went well, to enter the sacred space of the old Troy.

\section{Appendix: Linking Thessalians and Locrians}

If the ritual of the Thessalians can be seen as parallel to the ritual of the Locrian Maidens, then we should expect to find other parallelisms that link the Thessalians and Locrians together. Here are two possible examples:

1. At Iliad 5.530, the Locrian Ajax is described as excelling in spear-warfare among the pan-Hellēnes and the Achaeans ( Ajax is counted among all the Hellenes here, who are 'men from Hellas' just like the proto-Thessalian hero Achilles. At Iliad 2.683, the name Hellas is linked with Achilles and his men, who are the Myrmidons. In the next verse, at Iliad 2.684, the Myrmidons are linked with the Hellenes. In Philostratus, Heroikos 33.22, there is a brief aetiology explaining why all Thessalians are called Myrmidons. The reason, it is said there, is that the hero Protesilaos of Thessaly placed all his Thessalian warriors under the command of Achilles the Myrmidon.

2. In Lycophron $\Sigma 365.42-46$, we read that the Locrians send a ship every year to a point in the sea where Ajax the Locrian died, and, on board their ship, which is rigged with a black sail, they carry the fire they will use for making a thusia 'sacrifice' to the hero

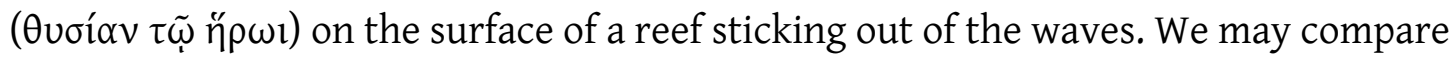
in Philostratus Heroikos 53.9 two details: (a) for their journey to the tomb of Achilles in the Troad to make a sacrifice to the hero there, the Thessalians sail on a ship that is rigged with a black sail, and (b) they bring with them on board the fire that they will use in making the sacrifice. 


\section{Bibliography}

Albersmeier, S., ed. 2009. Heroes: Mortals and Myths in Ancient Greece. Baltimore.

Aloni, A. 1986. Tradizioni arcaiche della Troade e composizione dell'Iliade. Milan.

Armstrong, R., and C. Dué, eds. 2006. The Homerizon: Conceptual Interrogations in Homeric Studies. Classics@ 3, http://chs.harvard.edu.

Aslan, Carolyn Chabot, and Rose, Charles Brian. 2013. City and Citadel at Troy from the Late Bronze Age through the Roman Period. Cities and Citadels in Turkey: From the Iron Age to the Seljuks (ed. Scott Redford and Nina Ergin) 7-38. Ancient Near Eastern Studies Supplement 40. Leuven/Paris/Walpole MA: Peeters.

Berenson Maclean, J. K., and E. B. Aitken, eds. 2001. Flavius Philostratus, Heroikos. Atlanta. The introduction, translation, and commentary are available at http://nrs.harvard.edu/urn-3:hlnc.primsrc:Berenson_MacleanJ_AitkenE_eds.Flavius_Philostratus_On_Heroes.2001.

Burgess. J. S. 2006. “Tumuli of Achilles." In Armstrong and Dué 2006, http://chs.harvard.edu.

Burgess, J. S. 2009. The Death and Afterlife of Achilles. Baltimore.

Cook, J. M. 1973. The Troad: An Archaeological and Topographical Study. Oxford.

Cook, J. M. 1984. "The Topography of the Plain of Troy.” The Trojan War: Its Historicity and Context, Papers of the First Greenbank Colloquium, Liverpool, 1981 (ed. L. Foxhall and J. K. Davies) 163-172. Bristol.

Ekroth, G. 2002. The Sacrificial Rituals of Greek Hero-Cults in the Archaic to the Early Hellenistic Periods. Liège.

Ekroth, G. 2009. “The Cult of Heroes.” In Albersmeier 2009:121-143.

Frame, D. 2009. Hippota Nestor. Hellenic Studies 37. Cambridge, MA and Washington, DC. http://nrs.harvard.edu/urn-3:hul.ebook:CHS_Frame.Hippota_Nestor.2009

Grossardt, P. 2006. Einführung, Übersetzung und Kommentar zum $<<$ Heroikos $>>$ von Flavius Philostrat I/II. Schweizerische Beiträge zur Altertumswissenschaft 33. Basel.

Haubold, J. 2004. "Serse, Onomacrito e la ricezione di Omero." Momenti della ricezione omerica (ed. G. Zanetto et al.) 19-35. Quaderni di Acme 67. Milan.

HPC. See Nagy 2010|2009.

LM. See Redfield 2003. 
Nagy, G. 2010|2009. Homer the Preclassic. Printed | Online version. Berkeley and Los Angeles. http://nrs.harvard.edu/urn3:hul.ebook:CHS_Nagy.Homer_the_Preclassic.2009.

Nagy, G. 2011. "The Aeolic Component of Homeric Diction." Proceedings of the 22nd Annual UCLA Indo-European Conference (ed. S[[tephanie]]. W. Jamison, H. C[[raig]]. Melchert, and B. Vine) 133-179. Bremen. In Nagy 2012 v1. http://nrs.harvard.edu/urn3:hlnc.essay:Nagy.The_Aeolic_Component_of_Homeric_Diction.2011

Nagy, G. 2012. "Signs of Hero Cult in Homeric Poetry." Homeric Contexts: Neoanalysis and the Interpretation of Homeric Poetry (ed. F. Montanari, A. Rengakos, and Ch. Tsagalis) 27-71. Trends in Classics Supplementary Volume 12. Berlin and Boston. http://nrs.harvard.edu/urn3:hlnc.essay:Nagy.Signs_of_Hero_Cult_in_Homeric_Poetry.2012.

Nagy, G. 2013. The Ancient Greek Hero in 24 Hours. Cambridge, MA. http://nrs.harvard.edu/urn3:hul.ebook:CHS_NagyG.The_Ancient_Greek_Hero_in_24_Hours.2013

Nagy, G. 2014. "Herodotus and the Logioi of the Persians." No Tapping around Philology: A Festschrift in Honor of Wheeler McIntosh Thackston Jr.'s 70th Birthday (ed. A.[[lireza]] Korangy and D.[[aniel]] J. Sheffield) 185-191. Wiesbaden [[Harrassowitz Verlag]]. http://nrs.harvard.edu/urn3:hlnc.essay:Nagy.Herodotus_and_the_Logioi_of_the_Persians.2014

Parker, H. 2008. "The linguistic case for the Aiolian Migration reconsidered." Hesperia 77:431464.

Redfield, James M. 2003. The Locrian Maidens: Love and Death in Greek Italy. Princeton.

Robertson, N. 1996. “Athena's Shrines and Festivals.” Worshipping Athena (ed. J. Neils) 27-77. Madison.

Rose, C. B. 2006. "Ilion." Stadtgrabungen und Stadtforschung im westlichen Kleinasien: Geplantes und Erreichtes (ed. W. Radt) 135-158. Istanbul.

Rose, C. B. 2008. "Separating Fact from Fiction in the Aiolian Migration." Hesperia 77:399-430.

Shaw, P. J. 2001. "Lords of Hellas, Old Men of the Sea: The Occasion of Simonides' Elegy on Plataea." The New Simonides: Contexts of Praise and Desire (ed. D. Boedeker and D. Sider) 164-181. Oxford.

West, M. L. 2002. "The View from Lesbos." Beiträge zur Homerforschung: Festschrift Wolfgang Kullmann (ed. M. Reichel and A. Rengakos) 207-219. Stuttgart. 